Christian Bigler • Lena Barnekow •

Markus L. Heinrichs • Roland I. Hall

\title{
Holocene environmental history of Lake Vuolep Njakajaure (Abisko National Park, northern Sweden) reconstructed using biological proxy indicators
}

Received: 4 March 2005 / Accepted: 16 January 2006 / Published online: 27 July 2006

(C) Springer-Verlag 2006

\begin{abstract}
Holocene environmental and climatic changes are reconstructed using analyses of biological proxies in lake sediments from Vuolep Njakajaure, a lake located near the altitudinal treeline in northern Sweden $\left(68^{\circ} 20^{\prime} \mathrm{N}\right.$, $18^{\circ} 47^{\prime} \mathrm{E}$ ). We analysed biological proxy indicators from both aquatic and terrestrial ecosystems, including diatoms, pollen and chironomid head capsules, in order to reconstruct regional Holocene climate and the development of the lake and its catchment. During the early Holocene and after $2500 \mathrm{cal}$ B.P., Fragilaria taxa dominated the diatom assemblages, whereas planktonic Cyclotella taxa prevailed during the major part of the Holocene (7800-2300 cal B.P.),
\end{abstract}

Communicated by Pim van der Knaap

C. Bigler $(\bowtie) \cdot$ M. L. Heinrichs · R. I. Hall

Department of Ecology and Environmental Science and Climate Impacts Research Centre CIRC, Umeå University,

KBC plan 5,

SE-901 87 Umeå, Sweden

e-mail: christian.bigler@emg.umu.se

C. Bigler

NCCR Climate, Institute of Plant Sciences,

University of Bern,

Altenbergrain 21,

CH-3013 Bern, Switzerland

L. Barnekow

Department of Quaternary Geology,

Lund University,

Sölvegatan 12 ,

SE-223 62 Lund, Sweden

e-mail: lena.barnekow@geol.lu.se

Present address:

M. L. Heinrichs

Limnologische Station der TU München,

Hofmark 3,

82393 Iffeldorf, Germany

e-mail: markus.heinrichs@wzw.tum.de

R. I. Hall

Department of Biology, University of Waterloo,

200 University Avenue West,

N2L 3G1 Waterloo, Ontario, Canada

e-mail: rihall@sciborg.uwaterloo.ca indicating the importance of the pelagic habitat for diatom assemblage composition. The planktonic diatoms appeared at the same time as Alnus became established in the catchment, probably altering nutrient availability and catchment stability. The pollen record is dominated by mountain birch (Betula pubescens ssp. tortuosa) pollen throughout the Holocene, but high percentage abundances of Scots pine (Pinus sylvestris) pollen suggest the presence of a mixed pine-birch forest during the mid-Holocene $(6800$ 2300 cal B.P.). Head capsules of Tanytarsini and Psectrocladius dominated the chironomid assemblage composition throughout the Holocene, in combination with Corynocera ambigua after 2300 cal B.P. A quantitative, diatom-based reconstruction of mean July air temperature indicated a relatively cold temperature during the early Holocene (9000 $8000 \mathrm{cal}$ B.P.) and after ca. $2300 \mathrm{cal}$ B.P., whereas the midHolocene period is characterised by stable and warm temperatures. The overall patterns of Holocene climate and environmental conditions are similarly described by all biological proxy-indicators, suggesting relatively warm conditions during the mid-Holocene (ca. 7800-2300 cal в.P.), with a subsequent colder climate after $2300 \mathrm{cal}$ B.P. However, the onset and magnitude of the inferred changes differ slightly among the proxies, illustrating different responses to lake development phases, land-uplift, and climate forcing (e.g., insolation patterns) during the Holocene in northern Sweden.

Keywords Diatoms $\cdot$ Pollen $\cdot$ Chironomids $\cdot$ Subarctic Sweden - Quantitative temperature reconstruction . Holocene

\section{Introduction}

In the light of exceptional climate conditions during the past decades, including warm summers and winters in Europe (Schär et al. 2004; Beniston 2005), the development of long-term records of environmental change and climate dynamics beyond the time-period covered by 
instrumental and monitoring data is increasingly important in the assessment of natural climatic variability. Arctic, subarctic and alpine regions are particularly vulnerable to climate change, as the extent of snow cover and permafrost, and the duration of ice-cover on lakes, rivers and streams might be reduced (Magnuson et al. 2000), with serious implications for the environment and society (Hassol 2004). These regions have generally limited historical instrumental records. However, at the same time the human activity causing land-use changes, pollution, and/or eutrophication and leading to unnatural altered conditions is comparably low. Therefore, these regions have a great potential for palaeoecological investigations based on natural archives and proxies to reconstruct past climatic and environmental conditions (Smol et al. 2005).

Among natural climate archives, lake sediments play an important role and contain not only information from the lake ecosystem itself (e.g. diatoms, chironomid larvae), but also from the surrounding landscape (e.g. pollen, spores, plant macrofossils). This makes it possible to study different organisms from ancient environments and their co-existence and responses to environmental change. Furthermore, the continuous accumulation of lake sediments allows the development of chronologies, an essential requirement when comparing different proxies and archives. This so-called "multi-proxy approach" is a powerful and widely accepted methodological approach, successfully applied at different locations and timescales (Ammann 2000; Birks et al. 2000; Oldfield and Berthier 2001).

The subarctic, mountainous landscape in northern Sweden offers an ideal setting for investigating past climate using the multi-proxy approach. Lakes are numerous, relatively easily accessible and located along broad climatic and ecological gradients. These include sites within coniferous forest dominated by Pinus sylvestris, mountain birch forest dominated by Betula pubescens ssp. tortuosa and alpine tundra situated above the tree-limit, formed by mountain birch at an elevation of 600-700 $\mathrm{m}$ a.s.l. The area is sensitive to climate change due to shifting influences of air masses with Atlantic or Arctic origin, leading to contrasting temperature and precipitation regimes (Shemesh et al. 2001; Hammarlund et al. 2002). For these reasons, many palaeoecological studies have been conducted in the region. Thus compared with other arctic and subarctic regions, the Abisko region probably offers the highest density of studies applying different methodological approaches to reconstruct past climate and environments. Karlén $(1976,1988)$ investigated tree relicts and glacial activity in sediments from proglacial lakes to reconstruct climatic conditions during the Holocene. Palaeoecological studies using pollen in peat profiles were initiated by Sonesson (1974), continued by Küttel (1984) and were later refined with a comprehensive investigation of pollen and plant macrofossil remains in lake sediments along an altitudinal transect by Berglund et al. (1996) and Barnekow (1999a, b). Pine trees were recovered and used for the reconstruction of past summer temperature from tree-rings
(Briffa et al. 1988; Grudd et al. 2002). Furthermore, pieces of wood from different tree species were recovered near a small lake above the treeline and used to reconstruct past tree-line fluctuations (Kullman 1999). Sedimentological studies of proglacial lake sediments were conducted in the Kårsa Valley, a valley adjacent to the main Abisko Valley, to establish past changes in glacial activity of the Kårsa glacier and in-lake processes (Snowball 1996; Snowball and Sandgren 1996). Past precipitation patterns have been reconstructed using oxygen isotope analysis of lake sediments (Berglund et al. 1996; Hammarlund et al. 2002) and subfossil diatoms (Shemesh et al. 2001).

Since the establishment of a palaeoecological research unit within the Climate Impact Research Centre at Abisko in 1997, extensive efforts have been made to assemble calibration sets for aquatic biological proxy-indicators in northern Sweden, namely diatoms (Bigler et al. 2000; Rosén et al. 2000; Bigler and Hall 2002) and chironomids (Larocque et al. 2001). This has been done in order to provide a basis for quantitative reconstruction of past climatic and environmental variables based on these organisms. Diatoms (Bacillariophyceae) are well-established palaeoenvironmental indicators and, for example, are sensitive to acidification, eutrophication and climate related variables. A large number of taxa exist with different ecological requirements (Stoermer and Smol 1999). Head-capsules of chironomid larvae (non-biting midges) have been shown to be valuable temperature indicators (Walker et al. 1991) and have become one of the most important zoological proxy indicators in lake sediments (Battarbee 2000). The calibration effort in northern Sweden has improved our knowledge of modern distribution patterns of diatoms and chironomids in subarctic regions and has provided a set of quantitative reconstruction tools, in the form of transfer functions, for lake-water $\mathrm{pH}$ (diatoms), July air temperature (diatoms, chironomids), and ice-cover duration (diatoms). The temperature models were validated by comparing reconstructions based on biological proxy indicators with instrumental climate data, for both diatoms (Bigler and Hall

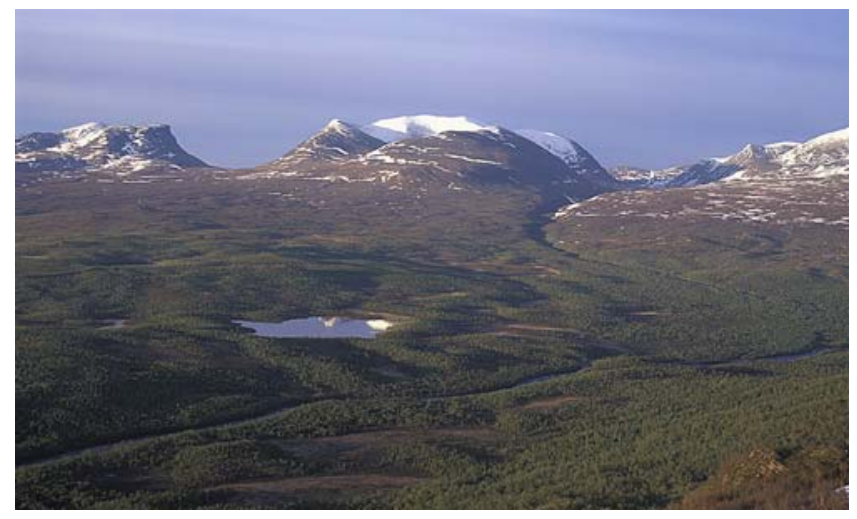

Fig. 1 Lake Vuolep Njakajaure within the Abisko National Park, the river Abiskojåkka (in the foreground) and its tributary Nissunjåkka (on the right) and the characteristic mountain formations including Lapporten ('The Gate to Lapland'). Photograph by Peter Rosén (June 2000) 


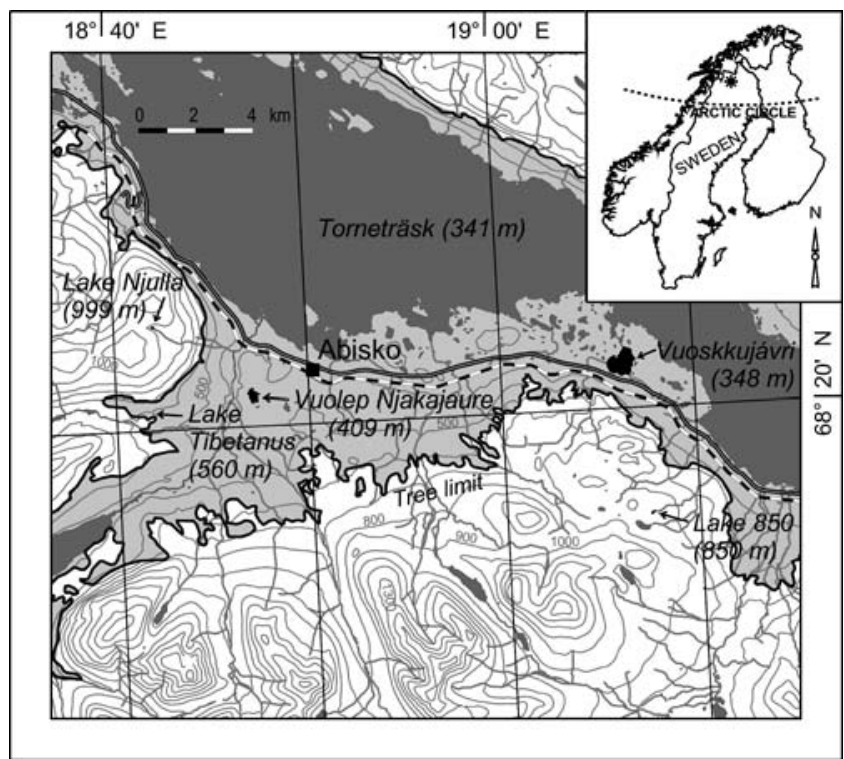

Fig. 2 Location of Vuolep Njakajaure, the route of the railway (built 1902; dashed line) and the road (built 1984). The locations of four additional lakes near Vuolep Njakajaure with multi-proxy palaeoenvironmental reconstructions are indicated

2003) and chironomids (Larocque and Hall 2003). In a next step, the models were applied to reconstruct quantitatively regional Holocene temperature and lake-water $\mathrm{pH}$ patterns based on sediment cores from lakes above the tree-line (Rosén et al. 2001; Bigler et al. 2003; Larocque and Bigler 2004; Larocque and Hall 2004), within the birch forest (Bigler et al. 2002; Larocque and Hall 2004) and within the mixed coniferous-birch forest (Heinrichs et al. 2005) in northern Sweden.

In this paper, we present the Holocene diatom stratigraphy from Lake Vuolep Njakajaure (henceforth referred to as Vuolep Njakajaure), a lake within the birch forest near Abisko (Figs. 1 and 2). We analyse the changes in diatom assemblage composition by means of Correspondence Analysis and provide a quantitative reconstruction of mean July air temperature by applying the regional diatom calibration set (Bigler and Hall 2002). In order to add to previous results based on multi-proxy approaches in the Abisko region, a main purpose of this study is also to compare diatom assemblage shifts with those of pollen (Barnekow 2000) and chironomids (Heinrichs et al. in press), assessing whether they are responding similarly to environmental changes. In contrast to other lakes investigated in the Abisko surroundings, Vuolep Njakajaure has partly calcareous bedrock in the catchment and the presentday lake-water $\mathrm{pH}$ is circumneutral. As a consequence of long-term natural acidification during the Holocene (Bigler et al. 2002, 2003), most other lakes show slightly acidic conditions (Bigler and Hall 2002). It has been shown that changes in lake-water $\mathrm{pH}$ may influence diatom-based temperature reconstructions (Bigler and Hall 2003). As the lake-water $\mathrm{pH}$ in Vuolep Njakajaure probably remained circumneutral during the entire Holocene, the diatom-based temperature reconstruction may be less affected by changes in lake-water $\mathrm{pH}$ than in other lakes.

\section{Material and methods}

Study site

Vuolep Njakajaure $\left(68^{\circ} 20^{\prime} \mathrm{N}, 18^{\circ} 47^{\prime} \mathrm{E}\right)$ is situated in the Abisko Valley, south of Lake Torneträsk and within the Abisko National Park, northern Sweden, at an elevation of $409 \mathrm{~m}$ a.s.l. (Figs. 1 and 2). The lake has a maximum depth of $13.7 \mathrm{~m}$, and is circumneutral (pH 7.5 in March 1997) (Barnekow et al. 1998).

In general, the vegetation in the Abisko Valley has a mosaic-like structure with patches of sparse mountainbirch forest (Betula pubescens ssp. tortuosa), with scattered and isolated stands of Scots pine (Pinus sylvestris) on favourable sites, and treeless heath and mire vegetation. The treeline is formed by mountain birch reaching up to 600-700 m a.s.l., while the upper limit of Scots pine reaches ca. 450 m a.s.l. (Barnekow 1999a, 2000). The Abisko Valley is in the rain shadow of the mountains to the west, and the measured annual precipitation is ca. $300 \mathrm{~mm}$. The mean annual temperature is $-0.8{ }^{\circ} \mathrm{C}$, with January the coldest and July the warmest month, reaching -11.9 and $11.0^{\circ} \mathrm{C}$ respectively (Fig. 3) (Alexandersson et al. 1991).

Fieldwork, sediment retrieval, depth-age model, and sample preparation

Overlapping sediment cores were collected in late winter 1991 from the deepest part of Vuolep Njakajaure (Barnekow et al. 1998) using a Russian coring device (Jowsey 1966). The collected cores were correlated using Saturated Isothermal Remanent Magnetisation (SIRM) analysis. In the lowest part $(343-334 \mathrm{~cm})$, the core consisted of grey, silty clay, followed by grey, laminated silty gyttja $(334-333 \mathrm{~cm})$. The main sequence of the Holocene core $(333-33 \mathrm{~cm})$ was described as dark-brown, laminated algal gyttja (with weak laminae between 65$33 \mathrm{~cm}$ ). The uppermost part was non-laminated, brown,

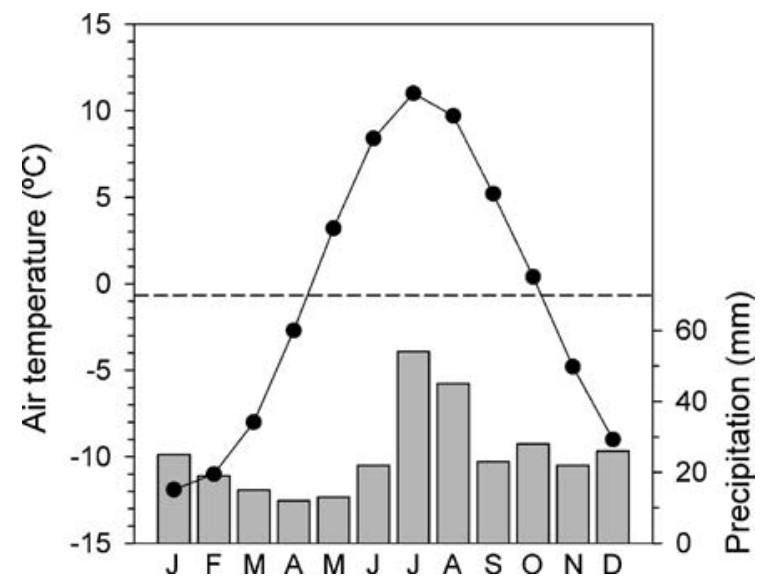

Fig. 3 Reference Normals (averages from 1961-1990) of monthly mean air temperature (solid dots), mean annual temperature (dashed line) and precipitation (vertical shaded bars) at Abisko (Abisko Scientific Research Station) (Alexandersson et al. 1991) 
fine-detritus gyttja (33-0 cm) (Barnekow 2000). After core correlation, the sediment core was sampled (1-cm slices, 8 -cm intervals) and analysed for pollen (Barnekow 2000), chironomids and diatoms.

The chronology is based on varve counting and AMS radiocarbon dates using plant macrofossils (Fig. 4). Because of the lack of identifiable laminations in the uppermost part of the sediment sequence $(65-0 \mathrm{~cm})$, the floating varve chronology was constrained by 17 calibrated radiocarbon dates, indicating that the uppermost $65 \mathrm{~cm}$ corresponds to 725 years (Barnekow et al. 1998). We assume a linear sedimentation rate for the uppermost sediment sequence (65$0 \mathrm{~cm}$ ). Additional details of the chronology development, such as varve counting procedures, type of plant macrofossils used for dating and calibration procedure are presented elsewhere (Barnekow et al. 1998).

Diatom samples were prepared and mounted using standard techniques according to Håkansson (1984). At least 400 diatom valves were counted in each sample using phase contrast optics at 1000× magnification. The diatom taxonomy was kept consistent with the regional calibration set (Bigler and Hall 2002), which largely followed Krammer and Lange-Bertalot (1986-1991).

Pollen samples were treated according to method A, as described by Berglund and Ralska-Jasiewiczowa (1986). At least 800 pollen grains were counted at each level at 400x and 1000x magnification. Identification followed Faegri and Iversen (1989) and comparisons were made with a reference collection at the Department of Quaternary Geology, Lund University. Betula pubescens ssp. tortuosa and Betula nana were distinguished according to locally collected reference samples and by comparing pore depth and grain size (Birks 1968; Mäkelä 1996).

Chironomid head capsules were extracted and analysed following a widely accepted protocol (Walker 2001).

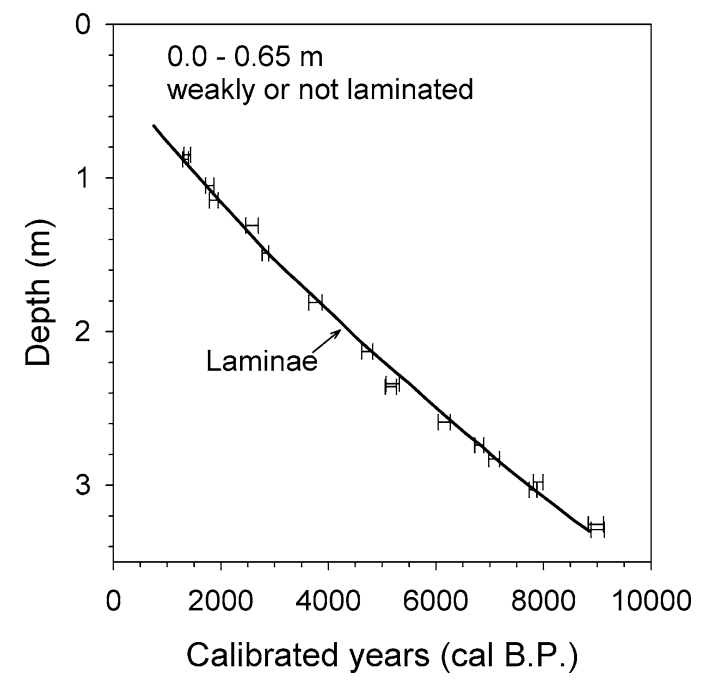

Fig. 4 Depth-age relationship of the Vuolep Njakajaure sediment record. The counted laminae (solid line) and AMS dated macrofossil samples with single standard deviation. The indistinctly and nonlaminated uppermost part $(65-0 \mathrm{~cm})$ corresponds to an estimated 725 yrs period
Sediment samples of known volumes were deflocculated using warm $5 \% \mathrm{KOH}$. The samples were sieved onto a $95 \mu \mathrm{m} \mathrm{Nitex}{ }^{\circledR}$-mesh to remove unwanted debris, and rinsed with $5 \% \mathrm{HCl}$ to dissolve any possible carbonates and neutralise residual $\mathrm{KOH}$. The remains were sorted using a Bogorov counting tray under 10-25x magnification. Identifications were made at 400-1000× magnification using keys by Walker (1988), Wiederholm (1983) and Oliver and Roussel (1983).

\section{Numerical analysis}

Zonation of the diatom stratigraphy of Vuolep Njakajaure was performed using optimal partitioning and the sum-ofsquares criteria (Birks and Gordon 1985) within the program ZONE (Lotter and Juggins 1991). The number of significant zones was assessed by comparison with the brokenstick model (Bennett 1996) and only statistically significant zones are presented. As the zonation of the pollen and chironomid stratigraphies was based on different methods in the original publications (Barnekow 2000; Heinrichs et al. in press), we recalculated zones for these records using the same methods as those used for the diatom data to ensure comparable zonation schemes for the three records.

To calculate the compositional turnover in the records, biostratigraphical data were analysed by Detrended Correspondence Analysis (DCA) using the program CANOCO (version 4.0) (ter Braak and Smilauer 1998). For this analysis, the data were square-root transformed to stabilise their variances and rare taxa were downweighted.

The quantitative reconstruction of mean July air temperatures using diatoms is based on a regional calibration set including surface sediments and environmental data from 100 lakes. We used Weighted Average Partial Least Squares (WA-PLS) regression and calibration (ter Braak and Juggins 1993) and the developed transfer function yielded a coefficient of determination $\left(r^{2}\right)$ of 0.75 and a root-mean-squared-error of prediction (RMSEP) of $0.96{ }^{\circ} \mathrm{C}$. Detailed information for the calibration set lakes and model development are given in Bigler and Hall (2002). From the Vuolep Njakajaure sediment core, we included all taxa available in at least three samples with $>1 \%$ in one sample in the quantitative temperature reconstruction. All of them were represented in the calibration set.

\section{Results}

Diatom stratigraphy

The 43 samples analysed for diatoms in the Holocene sediment sequence were generally rich in well-preserved diatoms, except for the two oldest samples that did not contain any diatoms and were therefore excluded from numerical analyses. In total, 140 taxa were identified in the remaining 41 samples and the diatom stratigraphy was divided into six stratigraphical zones based on the numerical zonation (Fig. 5). Small Fragilaria taxa were dominant 
during the early Holocene and since ca. 2800 cal B.P. (calibrated years before present), whereas the major part of the Holocene was dominated by planktonic Cyclotella taxa. In the following section, we briefly describe the most important characteristics of the diatom stratigraphy (Fig. 5).

The first zone (339-303 cm; > $7800 \mathrm{cal}$ B.P.) is dominated by small Fragilaria taxa (e.g., F. brevistriata, F. construens var. venter), a feature that is common in lake sediments of newly deglaciated terrain (Smol 1983). Fragilaria taxa may adapt quickly to changing environmental conditions (Lotter et al. 1999) and prosper in relatively high alkalinity conditions (Battarbee 1986; Bigler and Hall 2002). At the same time, a high relative abundance of Mastogloia smithii var. lacustris was recorded, a species preferring high conductivity and calcareous-rich conditions in littoral habitats (Krammer and Lange-Bertalot 1986-1991). Furthermore, Amphora libyca, Brachysira zellensis and Navicula diluviana reach their highest relative abundances in the first zone, all having ecological preferences that are similar to the other dominant taxa.

In the second zone $(303-231 \mathrm{~cm} ; 7800-5400 \mathrm{cal}$ B.P.), planktonic Cyclotella taxa such as $C$. comta, $C$. distinguenda and $C$. bodanica var. lemanica dominate, whereas Fragilaria taxa and Mastogloia smithii var. lacustris decrease. The appearance of planktonic taxa could be a result of an intensification of thermal stratification of the water column, leading to an increasing abundance of diatoms in the epilimnion. The third zone $(231-150 \mathrm{~cm}$; $5400-2900$ cal B.P.) is in general similar to the second zone, but with some shifts in relative abundance of the Cyclotella taxa. Specifically, $C$. distinguenda shows higher relative abundances and $C$. bodanica var. lemanica and $C$. comta decline in this zone. At the same time, Cyclotella comensis is recorded continuously, but at relatively low percentage (Fig. 5).

The fourth zone (150-142 cm; 2900-2700 cal в.P.) consists of one sample only, and more than $50 \%$ of the diatom sum is Cyclotella comensis. In the subsequent fifth zone (142-62 cm; 2,700-700 cal B.P.), the Cyclotella taxa show a decreasing trend, which is compensated for by an increasing abundance of mostly Fragilaria taxa (Fig. 5). This trend persists well into the sixth zone $(62-0 \mathrm{~cm} ;<700 \mathrm{cal}$ B.P.). In addition, Cyclotella comta is replaced by Cyclotella schumannii, which accounts for about $20 \%$ of the assemblages in the last zone.

\section{Vegetation history}

Using the optimal partitioning approach, three significant pollen zones were identified (Fig. 6). In the original vegetation description, five zones were established using a stratigraphically constrained cluster analysis (CONISS,

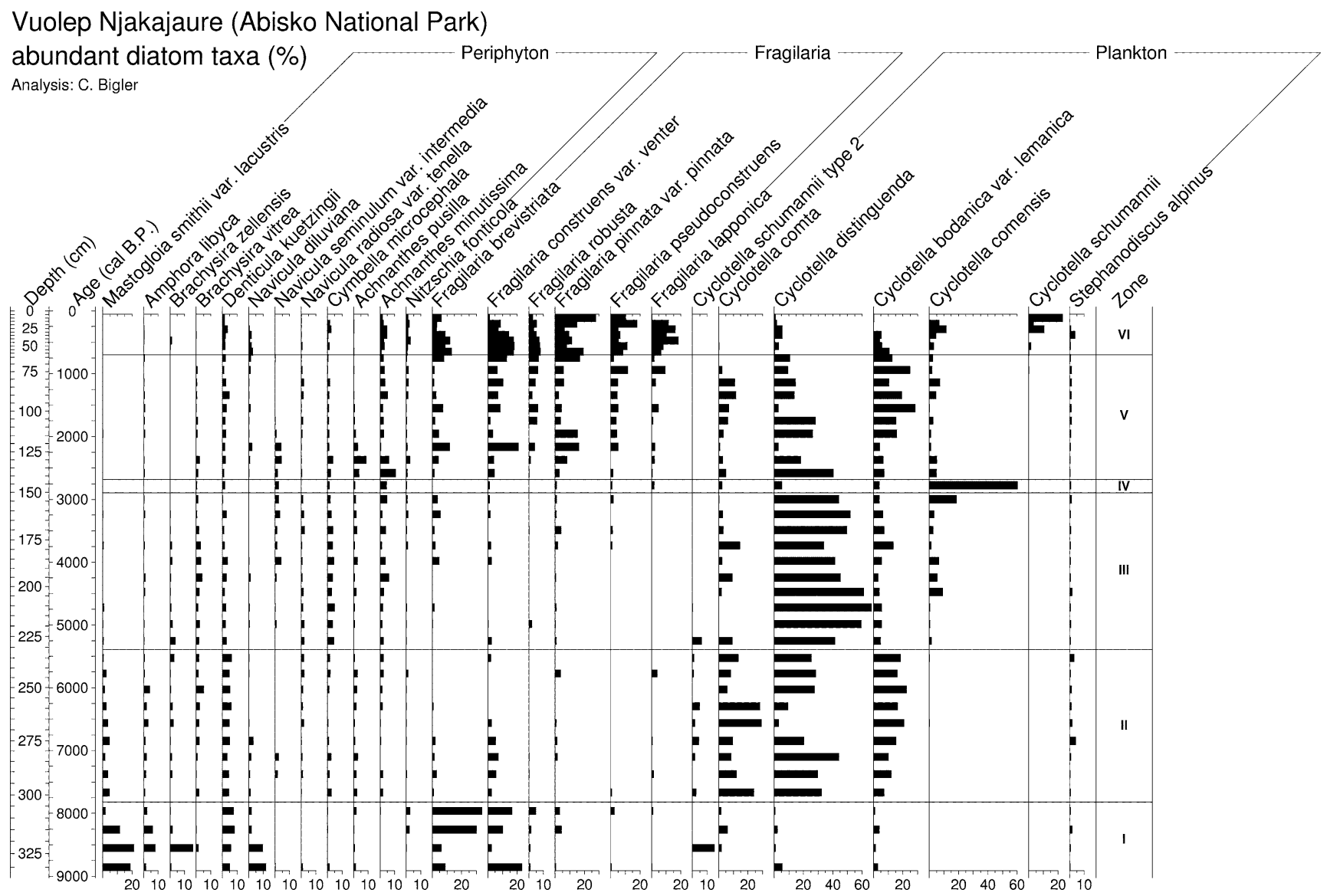

Fig. 5 Stratigraphical record of abundant diatom taxa in the sediment core from Vuolep Njakajaure (expressed as percentage abundance) 
Barnekow 2000). The original zonation differs in having additional divisions during the earliest part of the Holocene.

The pollen assemblage from the first zone $(335-273 \mathrm{~cm}$; $>6800$ cal B.P.) is dominated by Betula pubescens-type pollen, reaching values greater than $80 \%$. Based on evidence from Lake Badsjön (Barnekow 2000), a small lake nearby, mountain birch was already established regionally when organic sedimentation started in Vuolep Njakajaure. Organic sedimentation was considerably delayed, probably caused by dead-ice occupying the basin of this kettle lake (Barnekow 2000). The Pinus sylvestris pollen curve shows a slow rise in percentage abundance throughout the zone. The pollen-influx values indicate that single pine trees could have been present locally, even though most of the pollen probably arrived by long-distance wind transport (Barnekow 2000). Beside these two pollen types, the first pollen zone contains a relatively high abundance of Hippophaë rhamnoides pollen in the oldest sediments. Pteridophyte spores are present and relatively abundant mainly during the first part of the zone, whereas increasing values of Alnus and decreasing values of Betula nana-type pollen occurred in the second part of the zone (Fig. 6).

The second zone (273-129 cm; 6800-2300 cal в.P.) is characterised by relatively high Pinus sylvestris pollen abundances and a concomitant reduction of Betula pubescens-type pollen, indicating that pine-birch forest had developed regionally. In addition, Alnus, Juniperus and pteridophyte values decrease, in contrast to an increase in Ericales. From ca. 4300 cal B.P., spruce (Picea abies) pollen was continuously recorded at low percentage abundance in the pollen assemblages, even though spruce probably never colonised the lake catchment. At present, spruce reaches the Kiruna area, ca. $85 \mathrm{~km}$ east-southeast of Vuolep Njakajaure.
In the third zone $(129-0 \mathrm{~cm} ;<2300$ cal B.P.), Pinus sylvestris pollen decreases, while Betula pubescens-type pollen increases. In addition, Betula nana and to some extent Ericales and Poaceae increase. Thus the vegetation understorey was composed mainly of heath species, whereas during the early part of the Holocene herbs and ferns dominated.

\section{The chironomid record}

In Heinrichs et al. (in press), the chironomid record is divided into three zones, whereas zonation based on the optimal partitioning approach, including broken stick significance evaluation, identified only two significant zones (Fig. 6).

The first zone $(331-111 \mathrm{~cm},>1900 \mathrm{cal}$ B.P.) is dominated by $15-50 \%$ Tanytarsini (Fig. 6), however, Psectrocladius is also notably abundant throughout. The Tanytarsini are identified as having broad ecological tolerances to environmental variables in northern Sweden (Larocque et al. 2001), thus little information regarding climate or limnological state can be derived from the overwhelming abundance of this taxon. Sergentia, Microtendipes and Dicrotendipes are also present in the first zone and show a decreasing trend, while at the same time Chironomus and Cricotopus increase. This notable shift could possibly be related to changes in oxygen conditions, as a survey in Canada identified Chironomus as tolerant of low oxygen conditions, which is not the case for Sergentia (Quinlan and Smol 2001). Consequently, this shift within the first zone may suggest lower oxygen conditions in the lake. Furthermore, an increased abundance of littoral taxa (e.g.
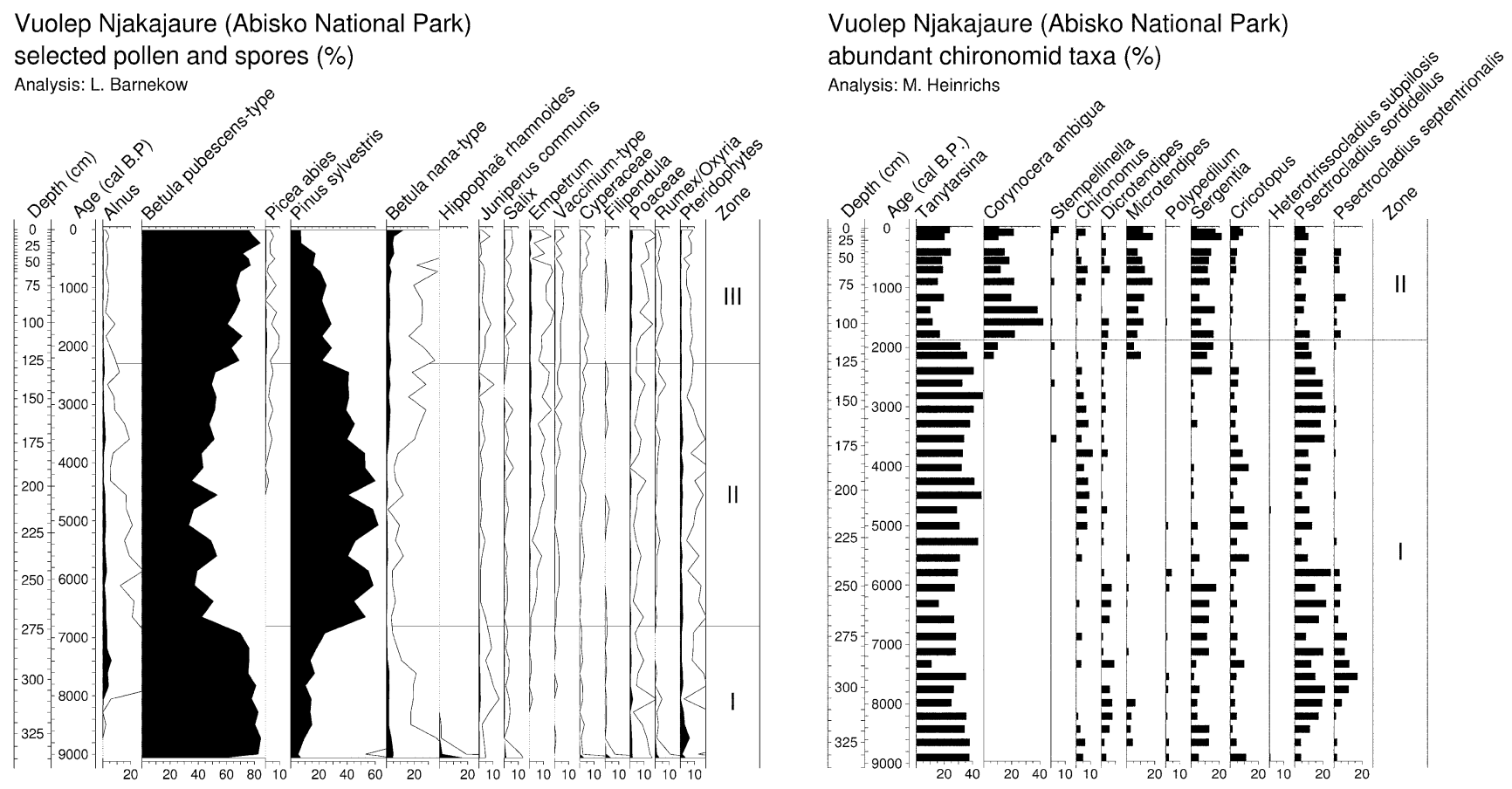

Fig. 6 Stratigraphical record of abundant pollen and spores (left panel, unshaded silhouettes are exaggerated at $\times 10$ scale) and chironomid head capsules (right panel) in the sediment core of Vuolep Njakajaure (expressed as percentage abundance) 
Cricotopus) was observed. Sergentia is often associated with cold conditions (Brooks and Birks 2000), but in cooler alpine or subarctic environments it is of little indicative value (Lotter et al. 1997; Olander et al. 1999). Overall, the chironomid assemblage composition suggests oligo-mesotrophic conditions.

The second zone $(111-0 \mathrm{~cm},<1900 \mathrm{cal}$ B.P.) is characterised by a sudden and dominant appearance of Corynocera ambigua. Tanytarsini decline to values around $20 \%$, whereas Microtendipes and Sergentia increased to 5-20\% and $10-20 \%$, respectively. Cricotopus and Psectrocladius were less abundant than in the previous zone. Microtendipes indicates warmer temperatures in northern Sweden (Larocque et al. 2001), but may also reflect an expanded littoral region in subarctic lakes.

Compositional turnover as assessed by correspondence analysis

The diatom sample scores of a Detrended Correspondence Analysis (DCA) show highest variability during the early Holocene, indicating that diatom assemblages experienced the most dramatic compositional changes during the earliest lake development stage (Fig. 7). Subsequently, stable and high DCA scores are recorded on the first DCA axis (eigenvalue $\lambda=0.31$ ) ca. 3800 cal B.P., after which values decrease. The second DCA axis $(\lambda=0.10)$ shows high scores during the early Holocene, reach lower scores afterwards, and display no clear trend after ca. $7000 \mathrm{cal}$ B.P.

The pollen DCA scores follow in general the established zones in Fig. 6. On the first axis $(\lambda=0.14)$, the scores initially show high values that decrease quickly and reach their lowest values between 6800 and $2300 \mathrm{cal}$ B.P. (note that axes are presented in inverse order for pollen to maximize concordance of patterns among the proxies). Subsequently, the scores increase slightly until present. The second axis $(\lambda=0.05)$ shows first low values that increase moderately and culminate around $6800 \mathrm{cal}$ B.P. In the remainder of the record, the scores on the second axis decrease linearly, showing the lowest values in the uppermost samples.

The main patterns of chironomid DCA axis 1 scores (Fig. 7) are to some extent related to the established zones (Fig. 6), and seem mainly driven by the appearance of Corynocera ambigua. The first axis $(\lambda=0.32)$ shows high scores initially, decreasing distinctly around the established zone boundary. The second DCA axis $(\lambda=0.08)$ shows no particular trend throughout the Holocene.

Quantitative reconstruction of July temperature using diatoms

The temperature inferred from the diatoms appears related to the ratio of planktonic diatoms to Fragilaria taxa (Fig. 8). Rises in Cyclotella abundance indicate, in general, high temperatures in northern Sweden, whereas Fragilaria taxa have rather lower temperature optima (Rosén et al.
2000; Bigler and Hall 2002). The diatom assemblages imply relatively low temperatures during the early Holocene (9000-8000 cal B.P.), reaching values around $12-13{ }^{\circ} \mathrm{C}$. Subsequently, temperature increased distinctly, and during the major part of the Holocene, the diatom assemblages indicate high temperatures $\left(14-15^{\circ} \mathrm{C}\right)$. At ca. $3000 \mathrm{cal}$ B.P., a gradual temperature decrease is reconstructed with low temperatures culminating at around $2000 \mathrm{cal}$ B.P. and during the past millennium (ca. $2{ }^{\circ} \mathrm{C}$ cooler than during the major part of the Holocene). Interestingly, the most recent sample suggests the lowest temperature (Fig. 8).

\section{Discussion}

Holocene lake development phases: early succession, climate optimum and climate deterioration

The early Holocene is probably the most difficult timeperiod for reconstructing past climatic and environmental conditions in northern Sweden. It is likely that ecosystems, both aquatic and terrestrial, were not in balance with the prevailing climatic conditions. During deglaciation, the melting of ice masses probably led to patchy landscapes, with notable spatial differences in environmental conditions. This is illustrated by the different timing of the onset of organic sedimentation, which was delayed in Vuolep Njakajaure by ca. 900 years compared to Lake Badsjön, a small lake located only a few hundred meters further to the east (Barnekow 2000). Vegetation was rather open during this time, and pollen spectra suggest wetter and warmer conditions than today (Barnekow 2000). During the early Holocene, remains of glaciers in the catchment were likely to have had a major impact on lake features such as stratification of the water column, light penetration and water temperature. For example, melting water could have affected Vuolep Njakajaure during the warm summer months, hampering the development of a stable stratification in the water column. This process is to some extent supported by the diatom record, as Fragilaria taxa, favouring a higher minerogenic input (Smol 1983) are abundant, whereas at the same time planktonic Cyclotella taxa, which require a stratified water column, show low abundances.

A major shift in both the pollen and diatom stratigraphy occurred at around $7800 \mathrm{cal}$ B.P. Alnus begins to become established, and pollen abundance and influx increase and reach the highest values recorded during the Holocene (Barnekow 2000). At the same time, the Fragilaria dominated diatom assemblage was replaced by a Cyclotella dominated community (Fig. 5). This shift probably indicates a reduction in minerogenic input and the development of stable lake stratification, allowing an increase of planktonic taxa. The ratio between planktonic and benthic diatoms in lake sediments has been used to reconstruct the effects of climate on lakes, based on the assumption that a high proportion of planktonic diatoms represents a prolonged season of open water (Lotter and Bigler 2000; Sorvari et al. 2002). In addition to increasing catchment stability, the establishment of Alnus also plays a major role 
Fig. 7 Detrended Correspondence Analysis (DCA) sample scores illustrating the compositional species turnover during the Holocene of the biological proxy-indicators in sediments from Vuolep Njakajaure
DCA axis 1
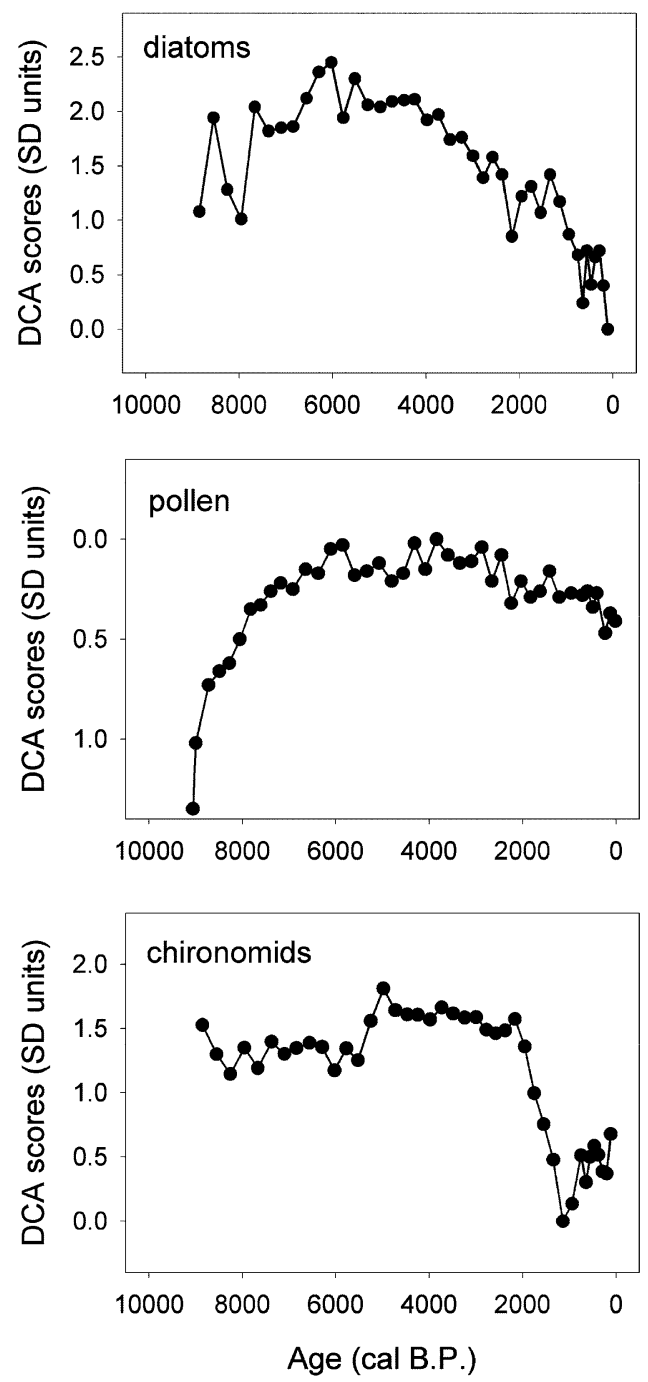

DCA axis 2
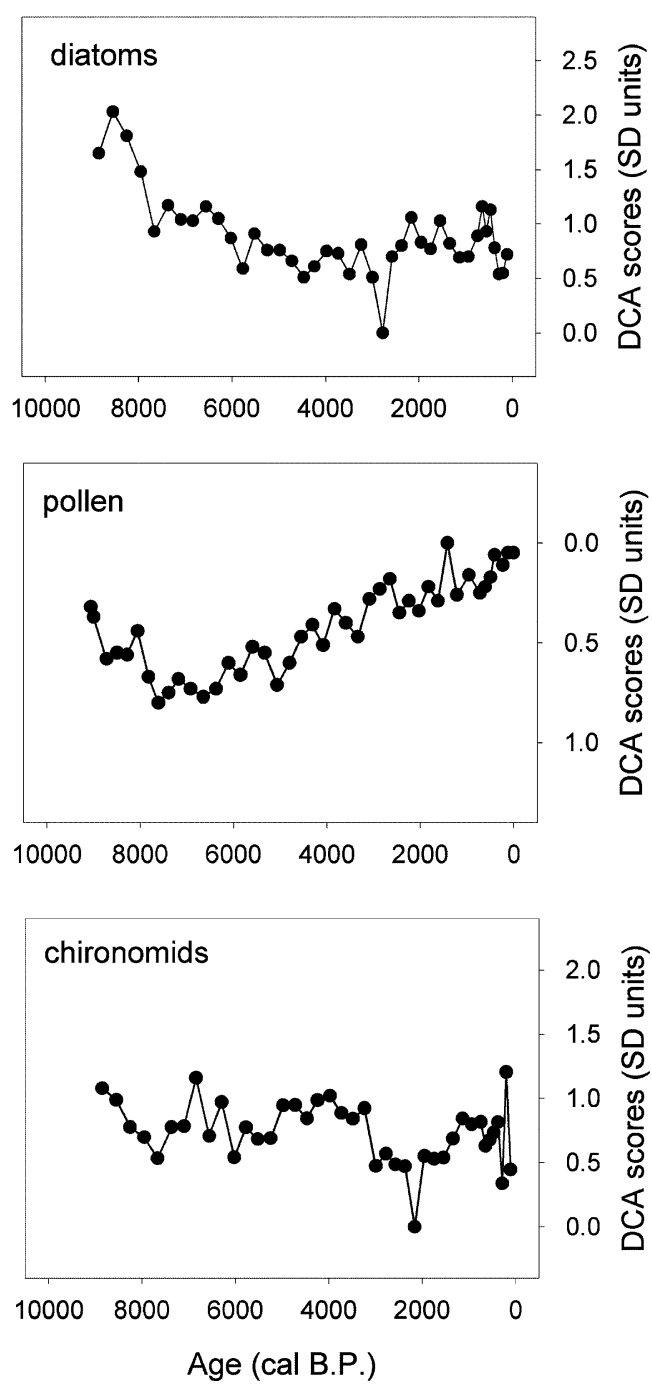

in the nitrogen budget. Alnus is able to fix atmospheric nitrogen, and as a result nitrogen concentrations in soils and at the lake shore probably increased. In an investigation of a chronosequence of newly deglaciated lakes in Alaska, the establishment of Alnus has been shown to have a major influence on lake chemistry and nutrient availability, with pronounced consequences for the diatom assemblage composition (Engstrom et al. 2000). From 7000-2500 cal B.P., the high abundance and influx of Pinus sylvestris pollen suggest maximum extension of pine-birch forest in the area, indicating particularly warm summer temperatures and dry conditions (Barnekow 1999b). This is in agreement with the July air temperatures inferred from the diatoms (Fig. 8) and from chironomids (Heinrichs et al. in press).

The pollen record suggests a climatic cooling at 4500 cal B.P., when Pinus influx decreases abruptly for a short time in Vuolep Njakajaure and also in nearby Badsjön (Barnekow 2000). Both diatoms and chironomids seem unaffected at this time. Pollen data suggest a further substantial temperature decrease at 2500 cal B.P., as the abundance of Pinus pollen decreases and, concomitantly, the abundance of heath species such as Betula nana, Poaceae and Ericales increase (Barnekow 2000). Contrary to the first temperature decrease inferred from pollen, at this time the diatoms and chironomids also show major changes in species composition patterns and temperature indications. The prevailing Cyclotella community is partly replaced by Fragilaria, which could be a result of reduced stratification and longer ice-cover duration. Subsequently, temperatures inferred from diatoms remain relatively low, indicating that the past two millennia were colder than the mid-Holocene (Fig. 8). Simultaneously, chironomids show a major change in community composition, as Tanytarsini decrease, whereas Corynocera ambigua appears and Microtendipes and Sergentia increase.

External factors affecting Vuolep Njakajaure:

land-uplift, insolation patterns

The glacio-isostatic land-uplift may have had an influence on prevailing climate and therefore on the quantitative 
Fig. 8 The abundance of Fragilaria and planktonic diatoms (mainly Cyclotella), pollen percentage abundance of Alnus, and mean July air temperature inferred from diatoms (DI-July T) in the Vuolep Njakajaure record. July insolation at $65^{\circ} \mathrm{N}$ is based on Berger and Loutre (1991)

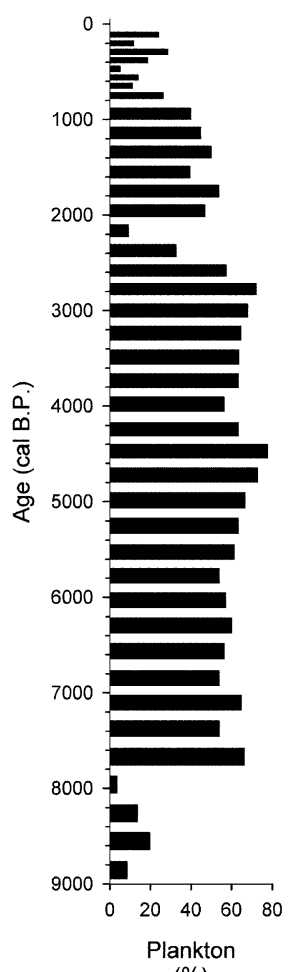

(\%)

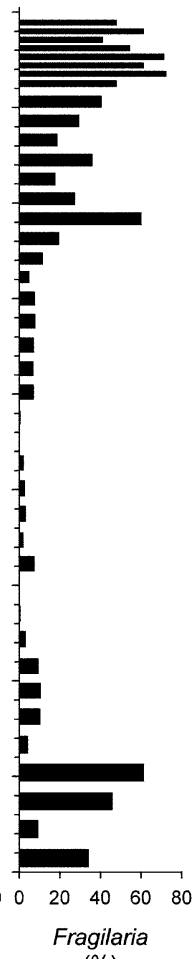

(\%)

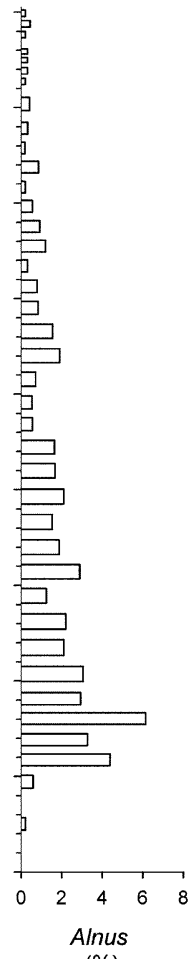

(\%)

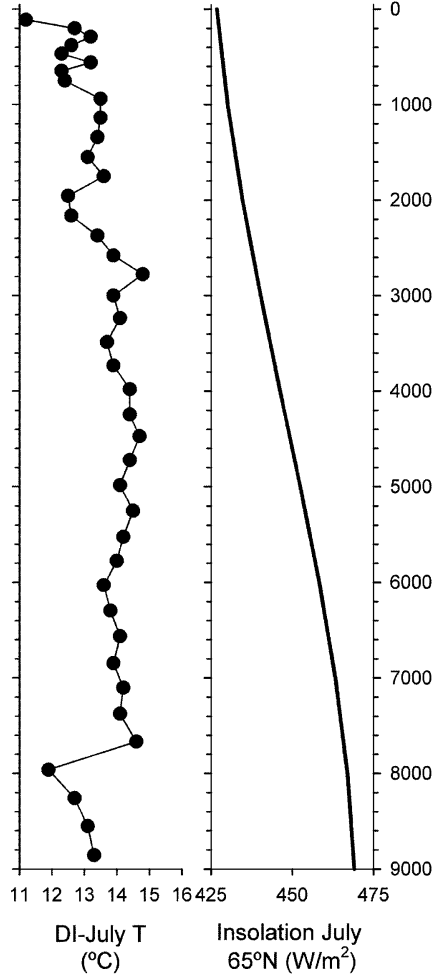

$\left({ }^{\circ} \mathrm{C}\right)$

$65^{\circ} \mathrm{N}\left(\mathrm{W} / \mathrm{m}^{2}\right)$ diatom based summer temperature reconstruction. Since 9000 cal B.P., the magnitude of regional land-uplift has been estimated to be ca. $100 \mathrm{~m}$ based on shore-line displacement (Renberg and Segerström 1981; Møller 1987). Applying the lapse rate for Fennoscandia of $0.57{ }^{\circ} \mathrm{C}$ per $100 \mathrm{~m}$ (Laaksonen 1976), the cooling due to land-uplift may account for some of the changes indicated by diatoms (Fig. 8). Our reconstruction is, however, not corrected for land-uplift.

Orbital forcing, the so-called Milankovitch-cycles, has a strong influence on latitudinal insolation patterns. Detailed reconstructions are available for periods exceeding the Holocene (Berger and Loutre 1991). Due to the location of Vuolep Njakajaure north of the Arctic Circle, the summer insolation was considerably higher during the early Holocene than today (Fig. 8), whereas the winter insolation remained consistently low. The change in summer insolation patterns certainly affected local climatic conditions, and was, in combination with the glacio-isostatic land-uplift, a major external factor regulating Holocene ecosystem dynamics in northern Sweden.

Comparison with regional quantitative climate reconstructions

Numerous palaeoecological studies have been carried out reconstructing past environmental conditions and climate in northern Sweden, particularly in the Abisko area. In this section, we compare our record with other quantitative reconstructions. At Lake Njulla, located above the presentday treeline (Fig. 2), chironomids and diatoms indicate warm summers during the early Holocene (Bigler et al. 2003). Elevated temperatures are suggested as well by fossil wood remains buried near the lake shore (Kullman 1999), a finding that is also supported by the pollen and macrofossil records of mountain birch from the same lake (Barnekow 1999a). At Lake 850 (Fig. 2), chironomids suggest a progressive temperature decline during the Holocene, whereas diatoms do not show any remarkable long-term trend (Larocque and Bigler 2004). At Lake Tibetanus (Fig. 2), summer temperatures were quantitatively reconstructed using pollen, and indicate a climate optimum during the midHolocene (Barnekow 1999a; Hammarlund et al. 2002). In Lake Vuoskkujávri, located today within the birch-forest (Fig. 2), chironomids suggest decreasing temperatures since the early Holocene. Both pollen and diatom indicators suggest similar patterns, but due to the lack of a good modern analogue, the reconstructions are tentative prior to 8000 (pollen) and 6000 (diatoms) cal B.P. (Bigler et al. 2002).

A similar study using quantitative multi-proxy reconstructions was carried out at Lake Sjuodjijaure in the Sarek Mountains (150 km south of our study area) where unstable and fluctuating climatic conditions were reconstructed for the early Holocene, followed by a mid-Holocene climatic optimum and progressively colder conditions during the past millennia (Rosén et al. 2001). In Lake Tsuolbmajavri, northern Finland, diatom-based reconstructions indicate only moderate temperature changes during the Holocene, suggesting that the coldest periods occurred during the early Holocene, at $4000 \mathrm{cal}$ B.P., $3000 \mathrm{cal}$ B.P. and during the past millennium (Korhola et al. 2000). Pollen-based reconstructions from the same core suggest a cool early Holocene, a mid-Holocene climate optimum and cooler 
temperatures since ca. 5700 cal B.P. (Seppä and Hammarlund 2000). Due to methodological constraints, a tree-ring record from the Torneträsk area showed no long-term Holocene climate trend, but accurately dated annual to centennial fluctuations (Grudd et al. 2002). However, a combination of low- and high-resolution proxies has a high potential for climate reconstructions in the Northern Hemisphere (Moberg et al. 2005) and this approach could probably lead to a more detailed synopsis of Holocene climate change in northern Sweden.

Precipitation reconstructions from Lake Tibetanus, based on pollen and oxygen isotopes, suggest relatively moist conditions during the early Holocene (600-800 mm annual precipitation) that subsequently decrease reaching present-day values from 4000 cal B.P. onwards (Hammarlund et al. 2002). Similarly, evidence from pollen from Lake Vuoskkujávri indicated a decreasing amount of annual precipitation since $7000 \mathrm{cal}$ B.P. (Bigler et al. 2002). In a regional context, comparable pollen-based precipitation patterns were reconstructed from Lake Tsuolbmajavri, northern Finland (Seppä and Birks 2001). An overall shift in dominating air masses is proposed for northern Scandinavia during the Holocene. Whereas moist Atlantic air masses dominated during the early Holocene, leading to relatively high precipitation, the influence of continental Arctic air masses increased progressively during the Holocene, leading to relatively dry conditions (Seppä and Hammarlund 2000; Seppä and Birks 2001; Shemesh et al. 2001; Hammarlund et al. 2002).

Our study confirms the patterns of Holocene climate and environmental conditions in northern Sweden described by many paleoenvironmental studies. During the early Holocene, pteridophytes indicate relatively moist conditions and diatom assemblages suggest relatively cool temperatures. The latter could be considerably affected by cold melting water and remaining ice in the lake catchment. As consequence, the largest differences between quantitative summer temperature reconstructions in northern Sweden based on biological proxy indicators in lake sediments exist during the early Holocene. After ca. 8000 cal B.P., diatoms in Vuolep Njakajaure suggest warm conditions, consistent with other regional temperature reconstructions that are all in relatively good agreement during the mid-Holocene. A regional climate deterioration, starting at ca. $4000 \mathrm{cal}$ B.P., is considerably delayed in the Vuolep Njakajaure record. Whereas diatoms indicate a temperature deterioration starting around ca. 3000 cal B.P., the pollen and chironomid record show a considerably delayed response (ca. $2300 \mathrm{cal}$ B.P. and 1900 cal B.P., respectively), demonstrating differences of response, both in timing and magnitude, among the proxies. It seems that lakes above the tree-line tend to respond more immediately than lakes within forested areas, highlighting the roles of the catchment properties of a lake and its position relative to ecotonal boundaries of the biota (Bigler et al. 2003). Unfortunately, dating uncertainties are considerable in many records and the resolution is relatively low, hampering an evaluation of the timing of colder and warmer periods on a finer temporal scale (Heegaard et al. 2006) .
Acknowledgements We dedicate this paper to Brigitta Ammann in honour of her retirement following an outstanding career. C.B. would like to thank her for all the inspiration, support, and encouragement during study and research periods in Bern.

We are grateful to $H$. Håkansson for preparing diatom slides and making them available for analysis. Special thanks to P. Rosén (www.rosenmedia.se) for providing the picture of Vuolep Njakajaure (Fig. 1) and to K. Aune for drawing Fig. 2. Finally, we acknowledge the comments by O. Heiri and G. Clarke who have greatly improved this manuscript.

\section{References}

Alexandersson H, Karlström C, Larsson-McCann S (1991) Temperature and precipitation in Sweden 1961-1990. Reference normals. Norrköping, SMHI report 81, 88 pp

Ammann B (2000). Biotic responses to rapid climatic changes: Introduction to a multidisciplinary study of the Younger Dryas and minor oscillations on a altitudinal transect in the Swiss Alps. Palaeogeogr Palaeoclimatol Palaeoecol 159:191-201

Barnekow L (1999a). Holocene tree-line dynamics and inferred climatic changes in the Abisko area, northern Sweden, based on macrofossil and pollen records. The Holocene 9:253265

Barnekow L (1999b) Holocene vegetation dynamics and climate changes in the Torneträsk area, northern Sweden. Lundqua Thesis 43, Dept. of Quaternary Geology. Lund University, Lund, 30 pp

Barnekow L (2000). Holocene regional and local vegetation history and lake-level changes in the Torneträsk area, northern Sweden. J Paleolimnol 23:399-420

Barnekow L, Possnert G, Sandgren P (1998). AMS 14C chronologies of Holocene lake sediments in the Abisko area, northern Sweden - a comparison between dated bulk sediment and macrofossil samples. GFF 120:59-67

Battarbee RW (1986) Diatom analysis. In: Berglund BE (ed) Handbook of Holocene palaeoecology and palaeohydrology. John Wiley \& Sons Ltd., Chichester, pp 527-570

Battarbee RW (2000) Palaeolimnological approaches to climate change, with special regard to the biological record. Quat Sci Rev 19:107-124

Beniston M (2005) Warm winter spells in the Swiss Alps: Strong heat waves in a cold season? A study focusing on climate observations at the Saentis high mountain site. Geophys Res Lett 32:L01812

Bennett KD (1996) Determination of the number of zones in a biostratigraphical sequence. New Phytol 132:155-170

Berger A, Loutre MF (1991) Insolation values for the climate of the last 10,000,000 years. Quat Sci Rev 10:297-317

Berglund BE, Ralska-Jasiewiczowa M (1986) Pollen analysis and pollen diagrams. In: Berglund BE (ed) Handbook of holocene palaeoecology and palaeohydrology. Wiley, Chichester, pp 455 484

Berglund BE, Barnekow L, Hammarlund D, Sandgren P, Snowball IF (1996) Holocene forest dynamics and climate changes in the Abisko area, northern Sweden - the Sonesson model of vegetation history reconsidered and confirmed. Ecol Bull 45:1530

Bigler C, Hall RI (2002) Diatoms as indicators of climatic and limnological change in Swedish Lapland: a 100-lake calibration set and its validation for paleoecological reconstructions. J Paleolimnol 27:97-115

Bigler C, Hall RI (2003) Diatoms as quantitative indicators of July temperature: a validation attempt at century-scale with meteorological data from northern Sweden. Palaeogeogr Palaeoclimatol Palaeoecol 189:147-160

Bigler C, Hall RI, Renberg I (2000) A diatom-training-set for paleoclimatic inferences from lakes in northern Sweden. Verhandlungen der Internationalen Vereinigung für Theoretische und Angewandte Limnologie 27:1174-1182 
Bigler C, Larocque I, Peglar SM, Birks HJB, Hall RI (2002) Quantitative multiproxy assessment of long-term patterns of Holocene environmental change from a small lake near Abisko, northern Sweden. The Holocene 12:481-496

Bigler C, Grahn E, Larocque I, Jeziorski A, Hall R (2003) Holocene environmental change at Lake Njulla (999 $\mathrm{m}$ asl), northern Sweden: a comparison with four small nearby lakes along an altitudinal gradient. J Paleolimnol 29:1329

Birks HH, Battarbee RW, Birks HJB (2000) The development of the aquatic ecosystem at Kråkenes Lake, western Norway, during the late glacial and early Holocene - a synthesis. J Paleolimnol 23:91-114

Birks HJB (1968) The identification of Betula nana pollen. New Phytol 67:309-341

Birks HJB, Gordon AD (1985) The analysis of pollen stratigraphical data. Zonation. In: Birks HJB, Gordon AD (eds) Numerical methods in Quaternary pollen analysis. Academic Press, London, pp 47-90

Briffa KR, Jones PD, Pilcher JR, Hughes MK (1988) Reconstructing summer temperatures in northern Fennoscandinavia back to A.D. 1700 using tree-ring data from Scots pine. Arctic Alpine Res 20:385-394

Brooks SJ, Birks HJB (2000) Chironomid-inferred late-glacial and early-Holocene mean July air temperatures for Kråkenes Lake, western Norway. J Paleolimnol 23:77-89

Engstrom DR, Fritz SC, Almendinger JE, Juggins S (2000) Chemical and biological trends during lake evolution in recently deglaciated terrain. Nature 408:161-166

Faegri K, Iversen J (1989) Textbook of pollen analysis. 4th edn. (revised by Faegri, K., Kaland, P. E. and Krzywinski, K.), Wiley, Chichester

Grudd H, Briffa KR, Karlén W, Bartholin TS, Jones PD, Kromer B (2002) A 7400-year tree-ring chronology in northern Swedish Lapland: natural climatic variability expressed on annual to millennial timescales. The Holocene 12:657-665

Håkansson H (1984) The recent diatom succession of Lake Havgårdssjön, South Sweden. In: Proceedings of the 7th Symposium in Fossil and Recent Diatoms, Philadelphia 1982, pp 411-429

Hammarlund D, Barnekow L, Birks HJB, Buchardt B, Edwards TWD (2002) Holocene changes in atmospheric circulation recorded in the oxygen-isotope stratigraphy of lacustrine carbonates from northern Sweden. The Holocene 12:339-351

Hassol SJ (2004) Impacts of a warming Arctic: Arctic climate impact assessment. Cambridge University Press, Cambridge, $144 \mathrm{pp}$

Heegaard E, Lotter AF, Birks HJB (2006) Aquatic biota and the detection of climate change: are there consistent aquatic ecotones? J Paleolimnol 35:507-518

Heinrichs M, Peglar SM, Bigler C, Birks HJB (2005) A multiproxy paleoecological analysis of Lake Alanen Laanijärvi, Swedish Lapland. Boreas 34:192-206

Heinrichs M, Barnekow L, Rosenberg S (in press) A comparison of chironomid biostratigraphy from Lake Vuolep Njakajaure with vegetation, lake-level, and climate changes in Abisko National Park, Sweden. J Paleolimnol

Jowsey PC (1966) An improved peat sampler. New Phytol 65:245248

Karlén W (1976) Lacustrine sediments and tree-limit variations as indicators of Holocene climatic fluctuations in Lappland, northern Sweden. Geografiska Annaler 3A:1-36

Karlén W (1988) Scandinavian glacial and climatic fluctuations during the Holocene. Quat Sci Rev 7:199-209

Korhola A, Weckström J, Holmström L, Erästö P (2000) A quantitative Holocene climatic record from diatoms in northern Fennoscandia. Quat Res 54:284-294

Krammer K, Lange-Bertalot H (1986-1991) Bacillariophyceae, vol 2. Fischer, Jena

Kullman L (1999) Early Holocene tree growth at a high elevation site in the northernmost Scandes of Sweden (Lapland): a palaeobiogeographical case study based on megafossil evidence. Geografiska Annaler 81A:63-74
Küttel M (1984) Vuolep Allakasjaure - eine pollenanalytische Studie zur Vegetationsgeschichte der Tundra in Nordschweden. Diss Bot 72 (Festschrift Welten):191-212

Laaksonen K (1976) The dependence of mean air temperatures upon latitude and altitude in Fennoscandia (1921-1950). Annales Academiae Scientiarium Fennicae 119:5-19

Larocque I, Bigler C (2004) Similarities and discrepancies between chironomid- and diatom-inferred temperature reconstructions through the Holocene at Lake 850, northern Sweden. Quat Int 122:109-121

Larocque I, Hall RI (2003) Chironomids as quantitative indicators of mean July air temperature: validation by comparison with century-long meteorological records from northern Sweden. J Paleolimnol 29:475-493

Larocque I, Hall RI (2004) Holocene temperature estimates and chironomid community composition in the Abisko Valley, northern Sweden. Quat Sci Rev 23:2453-2465

Larocque I, Hall RI, Grahn E (2001) Chironomids as indicator of climate change: A 100-lake training set from a subarctic region of northern Sweden (Lapland). J Paleolimnol 26:307322

Lotter AF, Bigler C (2000) Do diatoms in the Swiss Alps reflect the length of ice-cover? Aquatic Sci 62:125-141

Lotter AF, Juggins S (1991) POLPROF, TRAN and ZONE: programs for plotting, editing and zoning pollen and diatom data. Newsletter: INQUA-Subcommission for the Study of the Holocene Working Group on Data-Handling, Methods 6:4 6

Lotter AF, Birks HJB, Hofmann W, Marchetto A (1997) Modern diatom, cladocera, chironomid, and chrysophyte cyst assemblages as quantitative indicators for the reconstruction of past environmental conditions in the Alps. I. Climate. J Paleolimnol 18:395-420

Lotter AF, Pienitz R, Schmidt R (1999) Diatoms as indicators of environmental change near Arctic and Alpine treeline. In: Stoermer EF, Smol JP (eds) The diatoms: application to the environmental and earth sciences. Cambridge University Press, Cambridge, pp 205-226

Magnuson JJ, Robertson DM, Benson BJ, Wynne RH, Livingstone DM, Arai T, Assel RA, Barry RG, Card V, Kuusisto E, Granin NG, Prowse TD, Stewart KM, Vuglinsky VS (2000) Historical trends in lake and river ice cover in the northern hemisphere. Science 289:1743-1746

Mäkelä E (1996) Size distinctions between Betula pollen types-a review. Grana 35:248-256

Moberg A, Sonechkin DM, Holmgren K, Datsenko NM, Karlén W (2005) Highly variable Northern Hemisphere temperatures reconstructed from low- and high-resolution proxy data. Nature 433:613-617

Møller JJ (1987) Shoreline relation and prehistoric settlement in northern Norway. Norsk Geografisk Tidskrift 41:45-60

Olander H, Birks HJB, Korhola A, Blom T (1999) An expanded calibration model for inferring lakewater and air temperatures from fossil chironomid assemblages in northern Fennoscandia. The Holocene 9:279-294

Oldfield F, Berthier F (2001) The multi-proxy late-Pleistocene and Holocene record from the sediments of the Grand Lac d'Annecy, eastern France. J Paleolimnol 25:133-135

Oliver DR, Roussel ME (1983) The insects and arachnids of Canada, Part 11: The Genera of Larval Midges of Canada; Diptera: Chironomidae. Agriculture Canada, Publication 1746.

Quinlan R, Smol JP (2001) Chironomid-based inference models for estimating end-of-summer hypolimnetic oxygen from south-central Ontario shield lakes. Freshwater Biol 46:1529_ 1551

Renberg I, Segerström U (1981) The initial points on a shoreline displacement curve for southern Västerbotten, dated by varvecounts of lake sediments. Striae 14:174-176

Rosén P, Hall RI, Korsman T, Renberg I (2000) Diatom transferfunctions for quantifying past air temperature, $\mathrm{pH}$ and total organic carbon concentration from lakes in northern Sweden. J Paleolimnol 24:109-123 
Rosén P, Segerström U, Eriksson L, Renberg I, Birks HJB (2001) Holocene climatic change reconstructed from diatoms, chironomids, pollen and near-infrared spectroscopy (NIRS) at an alpine lake (Sjuodjijaure) in northern Sweden. The Holocene 11:551562

Schär C, Vidale PL, Lüthi D, Frei C, Häberli C, Liniger MA, Appenzeller C (2004) The role of increasing temperature variability in European summer heatwaves. Nature 427:332-336

Seppä H, Birks HJB (2001) July mean temperature and annual precipitation trends during the Holocene in the Fennoscandian treeline area: pollen-based climate reconstructions. The Holocene 11:527-539

Seppä H, Hammarlund D (2000) Pollen-stratigraphical evidence of Holocene hydrological change in northern Fennoscandia supported by independent isotopic data. J Paleolimnol 24:69-79

Shemesh A, Rosqvist G, Rietti-Shati M, Rubensdotter L, Bigler C, Yam R, Karlén W (2001) Holocene climatic change in Swedish Lapland inferred from an oxygen-isotope record of lacustrine biogenic silica. The Holocene 11:447-454

Smol JP (1983) Paleophycology of a high arctic lake near Cape Herschel, Ellesmere Island. Can J Bot 61:2195-2204

Smol JP, Wolfe AP, Birks HJB, Douglas MSV, Jones VJ, Korhola A, Pienitz R, Rühland K, Sorvari S, Antoniades D, Brooks SJ, Fallu MA, Hughes M, Bronwyn EK, Laing TE, Michelutti N, Nazarova L, Nyman M, Paterson AM, Perren B, Quinlan R, Rautio M, Saulnier-Talbot E, Siitonen S, Solovieva N, Weckström J (2005) Climate-driven regime shifts in the biological communities of arctic lakes. Proc Nat Acad Sci USA 102:43974402

Snowball IF (1996) Holocene environmental change in the Abisko region of northern Sweden recorded by the mineral magnetic stratigraphy of lake sediments. GFF 118:9-17
Snowball IF, Sandgren P (1996) Lake sediment studies of Holocene glacial activity in the Kårsa valley, northern Sweden: contrasts in interpretation. The Holocene 6:367-372

Sonesson M (1974) Late Quaternary forest development of the Torneträsk area, North Sweden, 2. Pollen analytical evidence. Oikos 25:288-307

Sorvari S, Korhola A, Thompson R (2002) Lake diatom response to recent Arctic warming in Finnish Lapland. Global Change Biol $8: 171-181$

Stoermer EF, Smol JP (eds) (1999) The diatoms: applications for the environmental and earth sciences. Cambridge University Press, Cambridge

ter Braak CJF, Juggins S (1993) Weighted averaging partial least squares regression (WA-PLS): an improved method for reconstructing environmental variables from species assemblages. Hydrobiologia 269/270:485-502

ter Braak CJF, Smilauer P (1998) CANOCO Reference Manual and Users' Guide to Canoco for windows 4.0: Software for Canonical Community Ordination. Microcomputer Power, Ithaca, NY

Walker IR (1988) Late-Quaternary palaeoecology of Chironomidae (Diptera: Insecta) from lake sediments in British Columbia. Simon Fraser University, Burnaby, 204 pp

Walker IR (2001) Midges: Chironomidae and related Diptera. In: Smol JP, Birks HJB, Last WM (eds) Tracking environmental change using lake sediments, vol 4. Zoological Indicators. Kluwer Academic Publishers, Dordrecht, pp 43-66

Walker IR, Smol JP, Engstrom DR, Birks HJB (1991). An assessment of chironomidae as quantitative indicators of past climatic change. Can J Fish Aquatic Sci 48:975-987

Wiederholm T (1983) Chironomidae of the Holarctic Region, Keys and Diagnoses: Part 1- Larvae. Entomol Scand Suppl 19:1-457 